Diterima : 28-5-2020 Revisi : 21-6-2020Ｄipublikasi : 25-6-2020

\title{
REPRESENTASI MASKULINITAS DALAM IKLAN GARNIER MEN VERSI JOE TASLIM DAN CHICO JERIKO
}

\author{
Herninda Cintia Kemala Sari \\ Program Studi Magister Ilmu Linguistik, Universitas Airlangga \\ Jl. Dharmawangsa Dalam, Airlangga, Gubeng, Kota Surabaya, Indonesia \\ Pos-el : hernindacintia22@gmail.com
}

\begin{abstract}
Television advertising is not only the most reliable medium for selling products, but also in shaping an image. Such as advertisements for facial care products for men which often highlight masculine images, where masculine is a gender concept that is pinned to men by a culture. This study aims to explore the meaning of denotation, connotation, and myth contained in the Garnier Men advertisement by Joe Taslim and Chico Jeriko. Using Roland Barthes's analysis related to signified, significant, denotative, connotative, and myth. The results showed a male masculine image, a combination of urban, metropolis, and metrosexual male images represented by denotations of races, martial arts and other urban metropolis men's activities. In connotation, showing a representation of the dominant male type in life. These signs point to the social relations of the community towards a man. This research is expected to be able to add and provide knowledge and be a reference for the public's perspective in interpreting television advertisements for men's facial cleansers.
\end{abstract}

Keywords : advertising, masculine, representation, semiotic

\begin{abstract}
Abstrak
Iklan televisi tidak hanya menjadi media yang paling diandalkan untuk menjual produk, namun juga dalam membentuk citra. Seperti iklan produk perawatan wajah untuk lakilaki yang sering menonjolkan citra maskulin, dimana maskulin merupakan konsep gender yang disematkan kepada laki-laki oleh suatu budaya. Penelitian ini bertujuan mengekplorasi makna denotasi, konotasi, dan mitos yang terdapat pada iklan Garnier Men versi Joe Taslim dan Chico Jeriko. Menggunakan analisis Roland Barthes terkait signified, signifier, denotatif, konotatif, dan mitos. Hasil penelitian menunjukkan adanya tampilan citra maskulin laki-laki, yaitu perpaduan antara citra laki-laki urban, metropolis, dan metroseksual yang direpresentasikan secara denotasi dari balapan, aksi bela diri dan kegiatan laki-laki urban metropolis lainnya. Secara konotasi, menampilkan representasi dari tipe laki-laki yang dominan dalam kehidupan. Tanda-tanda tersebut mengarah pada relasi sosial masyarakat terhadap seorang laki-laki. Penelitan ini diharapkan dapat menambah dan memberikan pengetahuan serta menjadi acuan bagi cara pandang masyarakat dalam memaknai iklan televisi pembersih wajah laki-laki.
\end{abstract}

Kata-kata kunci: iklan, maskulinitas, respresentasi, semiotika. 


\section{PENDAHULUAN}

Era digitalisasi seperti saat ini membuat perkembangan teknologi sangat mendominasi peran dalam kehidupan. Media massa contohnya, menjadi salah satu sarana yang dapat dengan mudah mempengaruhi pola pikir masyarakat. Padahal, di dalamnya sering dijumpai beberapa iklan yang secara tidak langsung dapat memperkuat stereotipe yang berkembang di masyarakat. Menurut Widyatama (2005), iklan merupakan pesan yang disampaikan komunikator atau sponsor dengan cara non personal kepada khalayak dan mengharapkan dampak tertentu.

Iklan juga seringkali menggunakan figur manusia dalam penyajiannya, dimana pesan yang ingin disampaikan akan lebih mudah sampai kepada khalayak. Seperti iklan televisi, yang tidak hanya menjadi media yang paling diandalkan untuk menjual produk, tetapi juga dalam membentuk citra. Pasalnya, banyak pengiklan menggunakan endorser terutama public figure dalam penyajian iklannya. Hal ini menjadi strategi penting, karena khalayak akan mengasosiasikan brand tersebut dengan public figure yang menjadi brand ambasador dengan mengaitkan kualitas endorser-nya. Salah satu jenis iklan yang melakukan hal tersebut ialah produk perawatan wajah untuk laki-laki, seperti sabun pembersih wajah laki-laki. Iklan produk perawatan wajah untuk laki-laki sering menonjolkan citra maskulin yang merupakan konsep gender yang disematkan kepada laki-laki oleh suatu budaya.

Di sisi lain, iklan juga dapat menjadi wacana dalam masyarakat. Hal ini dikarenakan iklan bermain dengan tanda dan bahasa. Seperti representasi maskulinitas yang dimainkan dengan tanda dan bahasa. Contohnya, iklan Garnier Men Versi Joe Taslim dan Chico Jeriko menampilkan citra maskulin perpaduan antara citra laki-laki urban, metropolis, dan metroseksual. Produk ini mencitrakan bahwa laki-laki juga butuh bersolek dalam keseharianya dengan menggunakan sabun pembersih wajah dimana kaum perempuan sudah terbiasa menggunakan sabun pembersih wajah untuk kebutuhan sehari-hari. Selain untuk membersihkan wajah juga berguna untuk menjaga kulit wajah agar senantiasa putih, bersih, dan sehat. Tanda-tanda yang ditemukan di dalam iklan Garnier Men ini terlihat melalui pemilihan artis yang digunakan. Yaitu dua orang lakilaki dewasa dengan gaya yang dipandang sebagai laki-laki macho, pemberani, dan metroseksual. Beberapa hal ini seringkali menggambarkan sisi maskulin dari seorang laki-laki. Maskulinitas ini bukanlah sebuah konstruksi biologis, melainkan sesuatu yang diperoleh melalui pengalaman dari proses sosialisasi. Dalam 
masyarakat yang menganut budaya patriarki, sifat-sifat maskulinitas ini umumnya digambarkan sesuai dengan ciri-ciri fisik laki-laki. Sehingga diharapkan dengan keadaannya yang demikian, lakilaki dapat memenuhi ekspektasi masyarakat yang dibebankan kepadanya melalui sifat-sifat maskulinitas. Diantaranya fisik yang kuat yang dapat dilihat dari tubuh berotot dan mental yang lebih tahan terhadap tekanan. Penggambaran sifat maskulinitas yang demikian ini dapat ditemui dalam berbagai bentuk.

Sementara, maskulinitas pada masa kini telah banyak digambarkan media dengan memperlihatkan bahwa laki-laki dengan sikap-sikap dan kriteria diatas dapat diterima oleh masyarakat. Dengan kata lain, media memperkenalkan bagaimana gambaran standar laki-laki yang dapat dikatakan maskulin. Penelitian ini akan membahas representasi maskulinitas yang ditampilkan pada iklan Garnier Men versi Joe Taslim dan Chico Jeriko. Penelitian ini bertujuan untuk mengeksplorasi makna denotasi, konotasi dan mitos yang terdapat pada iklan tersebut. Peneliti menggunakan analisis Roland Barthes tentang signified, signifier, denotatif, konotatif, dan mitos. Hasil penelitian secara denotasi menampilkan citra dari balapan yang merupakan kegiatan laki-laki metropolis. Namun secara konotasi, menampilkan representasi dari tipe laki-laki yang dominan dalam kehidupan. Pandangan masyarakat melalui tanda-tanda dalam iklan Garnier Men ini melalui gaya seorang laki-laki yang dipandang seperti laki-laki macho, laki-laki metroseksual, dan laki-laki pemberani.

\section{Teori Representasi}

Menurut Stuart Hall, representasi mengandung dua pengertian yaitu, pertama, representasi mental yang merupakan konsep tentang sesuatu yang ada di kepala kita masingmasing atau disebut juga sebagai peta konseptual. Representasi mental ini membentuk sesuatu yang abstrak. Kedua, representasi bahasa, representasi bahasa berperan penting dalam konstruksi makna. Konsep abstrak yang ada dalam kepala kita harus diterjemahkan dalam bahasa yang lazim, supaya kita dapat menghubungkan konsepkonsep dan ide-ide kita tentang suatu tanda dan simbol- simbol tertentu.

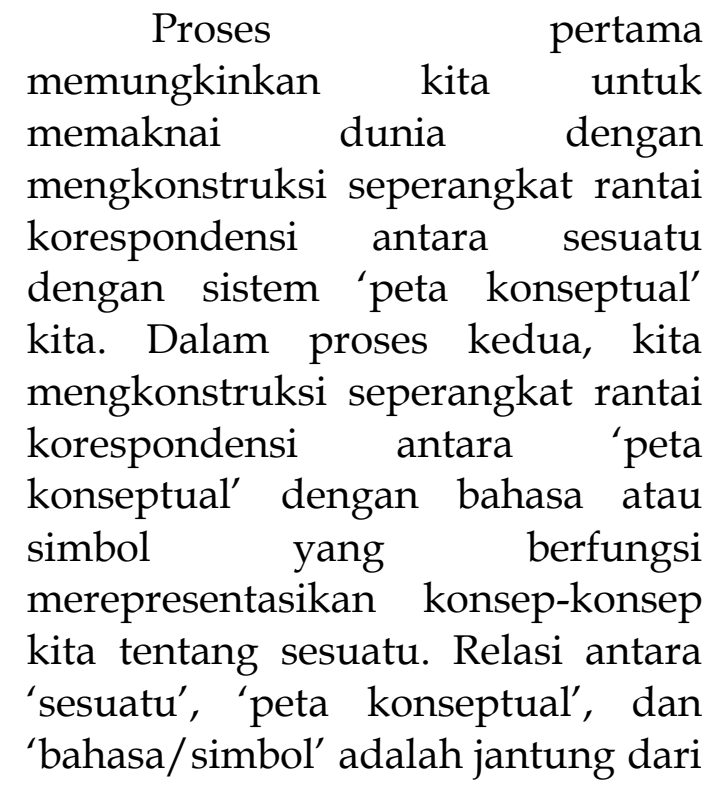


produksi makna lewat bahasa. Proses yang menghubungkan ketiga elemen ini secara bersama-sama itulah yang kita namakan representasi. Jadi dengan demikian representasi adalah proses sosial dari representing sekaligus produk dari representing itu sendiri.

Representasi menunjuk pada proses maupun produk dari pemaknaan suatu tanda. Representasi adalah konsep yang digunakan dalam proses sosial pemaknaaan melalui sistem penandaan yang tersedia, seperti dialog, video, film, teks, fotografi dan sebagainya. Representasi adalah produksi makna melalui bahasa. Untuk dapat menjelaskan bagaimana produksi makna hingga penggunaan dalam konstruksi sosial, Hall (1997) memetakannya menjadi tiga teori representasi. Pertama, pendekatan reflektif, yakni bahasa berfungsi sebagai cermin yang merefleksikan makna yang sebenarnya dari segala sesuatu yang ada di dunia. Dalam pendekatan reflektif, sebuah makna tergantung pada sebuah objek, orang, ide atau peristiwa di dalam dunia nyata. Bahasa pun berfungsi sebagai cermin yaitu untuk memantulkan arti sebenarnya seperti yang telah ada di dunia. Namun tanda visual membawa sebuah hubungan kepada bentuk dan tekstur dari objek yang direpresentasikan.

Kedua, pendekatan intensional, kita menggunakan bahasa untuk mengkomunikasikan sesuatu sesuai dengan cara pandang kita terhadap sesuatu. Pendekatan ini mengatakan bahwa sang pembicara, penulis atau siapapun yang mengungkapkan pengertiannya yang unik ke dalam dunia melalui bahasa.

Ketiga, pendekatan kontruksi, kita mengkonstruksi makna lewat bahasa yang kita pakai. Ini adalah pendekatan ketiga untuk mengenali publik, karakter sosial, dan bahasa. Sistem representasi dari pendekatan konstruksi ini meliputi suara, gambar, cahaya pada foto, coretancoretan yang kita buat atau representasi dapat juga disebut sebagai praktek dari jenis kerja yang menggunakan objek material. Namun demikian makna tidak tergantung pada kualitas material tanda, tetapi lebih kepada fungsi simbolik.

\section{Konsep Maskulinitas}

Maskulinitas merupakan konsep tentang peran sosial, perilaku dan makna-makna tertentu yang dilekatkan pada laki-laki diwaktu tertentu (Kimmel dan Aronson, 2002). Connell (2005) mengatakan, bahwa maskulinitas diletakkan pada relasi gender, yaitu praktik yang melibatkan laki-laki dan perempuan serta berimplikasi pada pengalaman jasmaniah, sifat, dan budaya. Menurut Barker (2001) maskulin merupakan sebuah bentuk konstruksi kelelakian terhadap lakilaki. Laki-laki tidak dilahirkan begitu saja dengan sifat maskulinnya secara alami, maskulinitas dibentuk oleh kebudayaan. Hal yang menentukan 
sifat perempuan dan laki-laki adalah kebudayaan. Secara umum, maskulinitas tradisional menganggap tinggi nilai-nilai antara kekuatan, kekuasaan, ketabahan, aksi, kendali, kemandirian, kepuasan diri, kesetiakawanan lakilaki, dan kerja keras. Diantara yang dipandang rendah adalah hubungan interpersonal, kemampuan verbal, kehidupan domestik, kelembutan, komunikasi, perempuan, dan anak-anak (Barker, 2001). Beynon

(2007) mendefinisikan maskulin merupakan laki-laki yang terlihat sangat "kebapakan", sebagai penguasa dalam keluarga, dan sosok yang mampu memimpin perempuan serta membuat keputusan yang utama.

Demartoto

(2009),

menyebutkan bahwa maskulinitas adalah sebuah konsep yang didekonstruksi oleh budaya sehingga konsepsi maskulinitas dalam suatu budaya dan budaya lainnya dapat berbeda.

kejantanan,

Maskulintas adalah imaji keperkasaan, keberanian untuk menantang bahaya, keuletan, keteguhan hati, hingga keringat yang menetes, otot laki-laki yang menyembul atau bagian tubuh tertentu dari kekuatan daya lakiaki yang terlihat secara ekstrinsik.

\section{Semiotika Roland Barthes}

\begin{tabular}{llr}
\multicolumn{2}{c}{ Cristomy dan } & Untung \\
Yuwono (2004:79) menyebut & meno \\
semiotika merupakan ilmu yang
\end{tabular}

mempelajari tentang tanda, fungsi tanda, dan produksi makna. Tanda adalah sesuatu yang bagi seseorang berarti sesuatu yang lain. Semiotik mengkaji tanda, penggunaan tanda dan segala sesuatu yang lain. Semiotik mengkaji tanda, penggunaan tanda, dan segala sesuatu yang bertalian dengan tanda. Dengan kata lain, perangkat pengertian semiotik yang meliputi tanda, pemaknaan, denotatum dan interpretan dapat diterapkan pada semua bidang kehidupan asalkan ada prasyaratnya dipenuhi, yaitu ada arti yang diberikan, ada pemaknaan dan ada interprestasi.

Menurut Barthes, semiologi hendak mempelajari bagaimana kemanusiaan memaknai hal-hal. Memaknai, dalam hal ini tidak dapat disamakan dengan mengkomunikasikan. Memaknai berarti bahwa objek-objek tidak hanya membawa informasi, dalam hal mana objek-objek itu hendak berkomunikasi, tetapi juga mengkonstitusi sistem struktural dari tanda. Barthes dengan demikian signifikasi sebagai sebuah proses yang total dengan suatu susunan yang sudah terstruktur. Signifikasi tak terbatas pada bahasa, tetapi juga pada hal-hal lain diluar bahasa. Barthes menganggap kehidupan sosial sebagai sebuah signifikansi. Dengan kata lain, kehidupan sosial, apa pun bentuknya, merupakan suatu sistem tanda tersendiri (Kurniawan, 2001: 53).

Teori semiotik Barthes hampir secara harfiah diturunkan 
dari teori bahasa menurut de Saussure. Roland Barthes mengungkapkan bahwa bahasa merupakan sebuah sistem tanda yang mencerminkan asumsi-asumsi dari masyarakat tertentu dalam waktu tertentu (Sobur, 2003: 63). Selanjutnya Barthes menggunakan teori signifiant-signifie yang dikembangkan menjadi teori tentang metabahasa dan konotasi. Istilah signifiant menjadi ekspresi dan signifie menjadi isi. Namun, Barthes mengatakan bahwa antara antarasignifiant dan signifie harus ada relasi tertentu, sehingga membentuk tanda. Konsep relasi ini membuat teori tentang tanda lebih mungkin berkembang karena relasi ditetapkan oleh pemakai tanda. Sebagaimana pandangan Saussure, Barthes juga meyakini bahwa hubungan antara penanda dan petanda tidak terbentuk secara alamiah, melainkan bersifat arbiter. Bila Saussere hanya menekankan pada penandaan dalam tataran denotatif, maka Roland Barthes menyempurnakan semiologi Saussure dengan mengembangkan sistem penandaan pada tingkat konotatif. Barthes juga melihat aspek lain dari penandaan, yaitu mitos yang menandai suatu masyarakat.

Dari peta Barthes di atas terlihat bahwa tanda denotatif terdiri atas penanda dan pertanda. Akan tetapi, pada saat bersamaan, tanda denotatif adalah juga penanda konotatif. Denotasi dalam pandangan Barthes merupakan tataran pertama yang maknanya bersifat tertutup. Tataran denotasi menghasilkan makna yang eksplisit, langsung dan pasti. Denotasi merupakan makna yang sebenarbenarnya, yang disepakati bersama secara sosial, yang rujukannya pada realitas. Tanda konotatif merupakan tanda yang penandanya mempunyai keterbukaan makna atau makna yang implisit, tidak langsung, dan tidak pasti, artinya terbuka kemungkinan terhadap penafsiran-penafsiran baru. Dalam semiologi Barthes, denotasi merupakan sistem signifikansi tingkat pertama, sedangkan konotasi merupakan sistem signifikansi tingkat kedua. Denotasi dapat dikatakan merupakan makna objektif yang tetap, sedangkan konotasi merupakan makna subjektif dan bervariasi. Dalam kerangka Barthes, konotasi identik dengan operasi ideologi, yang disebutnya sebagai 'mitos' dan berfungsi untuk mengungkapkan dan memberikan pembenaran bagi nilai-nilai dominan yang berlaku dalam satu periode tertentu. Di dalam mitos juga terdapat pola tiga dimensi penanda, pertanda, dan tanda. Namun, sebagai suatu sistem yang unik, mitos dibangun oleh suatu rantai pemaknaan yang telah ada sebelumnya atau dengan kata lain, mitos juga suatu sistem pemaknaan tataran kedua. Di dalam mitos pula, sebuah pertanda dapat memiliki beberapa penanda (Budiman dalam Sobur, 2004: 71).

Selain denotasi dan konotasi dalam tatanan simbolik menurut Barthes, ada satu bentuk penandaan 
yang disebut sebagai mitos. Mitos dapat dikatakan sebagai ideologi dominan pada waktu tertentu. Denotasi dan konotasi memiliki potensi untuk menjadi ideologi yang bisa dikategorikan sebagai konsep mitos. Mitos adalah sebuah kisah yang melaluinya sebuah budaya menjelaskan dan memahami beberapa aspek dari realitas (Fiske dalam Jhayanti, 2013: 37). Mitos membantu kita untuk memaknai pengalaman-pengalaman kita dalam satu konteks budaya tertentu. Barthes berpendapat bahwa mitos melakukan naturalisasi budaya, dengan kata lain, mitos membuat budaya dominan, nilai-nilai sejarah, kebiasaan dan keyakinan yang dominan terlihat "natural", "abadi", "masuk akal", "objektif", dan "benar biacara apa adanya"

Dalam pandangan Barthes petanda bukanlah "benda", tetapi representasi mental dari "benda". Saussure sendiri telah menyebut haikat mental petanda itu dengan istilah "konsep". Petanda dari kata "sapi", misalnya, bukanlah binatang sapi, tetapi imaji mental tentang sapi itu. Hakikat penanda sama saja dengan petanda, yaitu secara murni adalah sebuah relatum yang batasannya tak dapat dipisahkan dari petanda. Satu-satunya perbedaannya dengan petanda adalah bahwa penanda merupakan sebuah mediator, suatu hal yang perlu untuknya.

Sebagai mediator substansi penanda selalu merupakan materi (suara, obyek, imaji).
Pengklasifikasian penanda juga tak ada, sama dengan petanda (Barthes, 2017: 46). Tanda dan makna merupakan kata kunci yang menghubungkan antara semiotika dan komunikasi. Di dalam komunikasi terdapat unsur pesan yang terbentuk tanda-tanda. Dan tanda-tanda ini mempunyai struktur tertentu yang dilatarbelakangi oleh keadaan sosiologi ataupun budaya di tempat komunikasi itu hidup sehingga untuk mempelajari bagaimana struktur pesan atau konteks di balik pesan-pesan komunikasi diperlukan studi semiotika terlebih dalam komunikasi massa (Yohanda, 2011: 43).

\section{Kerangka Pemikiran}

Maskulinitas merupakan hal yang tidak pernah lepas dari lakilaki. Tidak sedikit laki-laki yang berlomba-lomba untuk menjadi maskulin sesuai apa yang orang lain inginkan, laki-laki yang tidak masuk kedalam kategori maskulin harus menyesuaikan diri dengan apa maskulinitas yang selama ini telah menjadi tuntunan masyarakat. Ketika laki-laki merasa tidak percaya diri dengan apa yang dimilikinya, hal tersebut membuat semua orang bertanya bagaimana definisi maskulin selama ini yang diinginkan masyarakat serta bagaimana maskulinitas yang selama ini media munculkan kepada khalayak, sehingga mengubah persepsi masyarakat tentang makna maskulin yang sebenarnya. 
Dari uraian diatas kerangka pemikiran dalam penelitian ini adalah dari Garnier Men versi Joe Taslim dan Chico Jerikho akan dianalisis dengan menggunakan semiotika Roland Barthes yang terdiri dari,

a. Denotasi, merupakan pemahaman terhadap apa yang ada dalam gambar.

b. Konotasi, makna yang ada di balik gambar.

Setelah itu, analisis maskulinitas dalam iklan Garnier Men versi Joe Taslim dan Chico Jerikho akan didapatkan sebagai kesimpulan dari penelitian ini.

\section{METODE PENELITIAN}

Penelitian ini menggunakan metode penelitian kualitatif. Metode kualitatif merupakan metode penelitian yang digunakan untuk meneliti pada kondisi obyek yang alamiah, dimana penelitian adalah sebagai instrumen kunci, teknik pengumpulan data dilakukan secara triangulasi (gabungan), analisis data bersifat induktif/kualitatif, dan hasil penelitian kualitatif lebih menekankan makna dari pada generalisasi.

Untuk mempermudah penelitian yang dilakukan maka yang menjadi fokus penelitian adalah untuk mengetahui simbolsimbol atau tanda-tanda maskulinitas yang terdapat pada iklan pembersih wajah laki-laki Garnier Men dan memberikan gambaran secara keseluruhan mengenai makna maskulin yang disampaikan dalam iklan pembersih wajah laki-laki Garnier Men di televisi.

Iklan ini akan dieksplorasi berdasarkan unit-unit gambarnya dengan menggunakan metode semiotika Roland Barthes yang akan membongkar isi pesan dalam iklan, dimana kita ketahui bahwa televisi memiliki dua aspek yaitu audio dan visual. Untuk mengetahui makna dari tanda-tanda yang ditampilkan dari kedua aspek tersebut, maka peneliti membuat instrumen penelitian yang meliputi tokoh, ekpresi tokoh, setting, kata-kata narasi, penampilan fisik tokoh, suara, dan sound effect.

\section{HASIL DAN PEMBAHASAN}

Hasil penelitian yang telah dilakukan berkenaan dengan representasi maskulinitas pada iklan Garnier Men versi Joe Taslim dan Chico Jeriko ditinjau melalui pendekatan kualitatif dengan menggunakan metode teknik analisis semiotika Roland Barthes. Teknik analisis semiotika Roland Barthes mengutamakan pengungkapan makna denotasi, makna konotasi dan diperkuat oleh mitos-mitos yang dilandasi dari ideologi dominan pada objek penelitian yang tersembunyi pada adegan-adegan di setiap scene dari iklan tersebut.

Dalam sebuah iklan yang menekankan satu identitas tertentu, terdapat makna tersirat maupun makna tersurat yang sengaja ditampilkan oleh pembuat iklan pada sebuah iklan. Hal ini juga terdapat pada iklan Garnier Men 
versi Joe Taslim dan Chico Jeriko dimana identitas yang menonjol dalam iklan ini adalah identitas yang biasa muncul pada konsep maskulinitas.

$$
\text { Unit analisis dalam }
$$

penelitian ini berfokus pada potongan scene iklan sebagai tanda non-verbal dan narasi iklan sebagai tanda verbal. Tanda-tanda yang dianalisis dalam iklan ini merupakan tanda-tanda yang memiliki representasi konsep maskulinitas. Adapun tanda yang dianalisis yaitu tanda verbal, meliputi narasi yang terdapat pada iklan. Dan tanda non verbal, meliputi setting latar, objek gambar, tampilan fisik, pakaian yang dipakai, transportasi, gerakan tubuh, ekspresi wajah, pengambilan gambar.

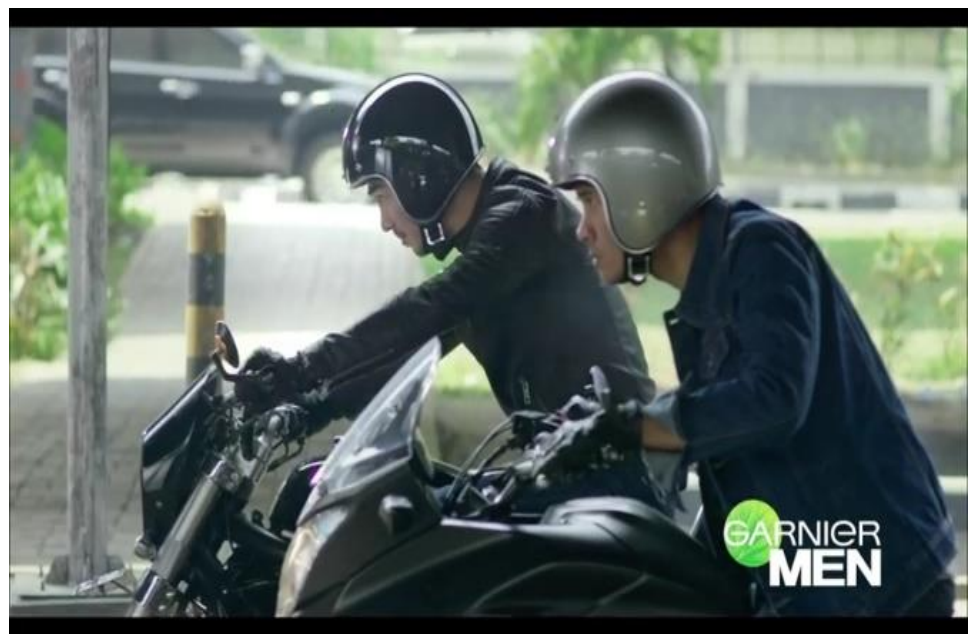

Melalui analisis terhadap Garnier Men versi Joe Taslim dan Chico Jeriko dapat ditemukan tanda-tanda semiotik, yakni latar tempat yang berada di tengah kota metropolitan dengan banyak bangunan gedung bertingkat dan lalu lalang kendaraan khususnya mobil.

Pada potongan scene di atas menggambarkan laki-laki yang berpenampilan rapi dengan jaket kulit dan jaket jeans mengendarai motor besar. Pada adegan ini, iklan Garnier Men memberikan makna denotasi terhadap dua sosok lakilaki yang berpenampilan dengan gaya macho, dimana kedua laki-laki tersebut terlihat gagah dengan menggunakan jaket dan mengendarai motor besar khas lakilaki yang menjadikan laki-laki dalam iklan tersebut menjadi lakilaki yang keren, modis, dan modern. Sementara, makna konotasi dalam potongan scene di atas ialah gaya menjadi modal utama bagi laki-laki dalam berpenampilan karena penampilan suatu hal yang wajib bagi seorang laki-laki dalam kehidupan sehari-hari yang mana hal tersebut merupakan konsep maskulinitas tipe laki-laki ibu kota. Hal ini diperkuat dengan mitos atau ideologi yang berkembang di dalamnya, yakni semua karakter atau sifat seseorang terbentuk karena kondisi sosial. Seorang laki- 
laki bisa menjadi seorang laki-laki yang benar-benar maskulin ketika lingkungan di sekitar mendukung untuk itu, laki-laki akan menjadi seorang laki-laki macho apabila lingkungan mendukung untuk menjadikannya dia macho seperti pada seorang dalam iklan Garnier Men tersebut.

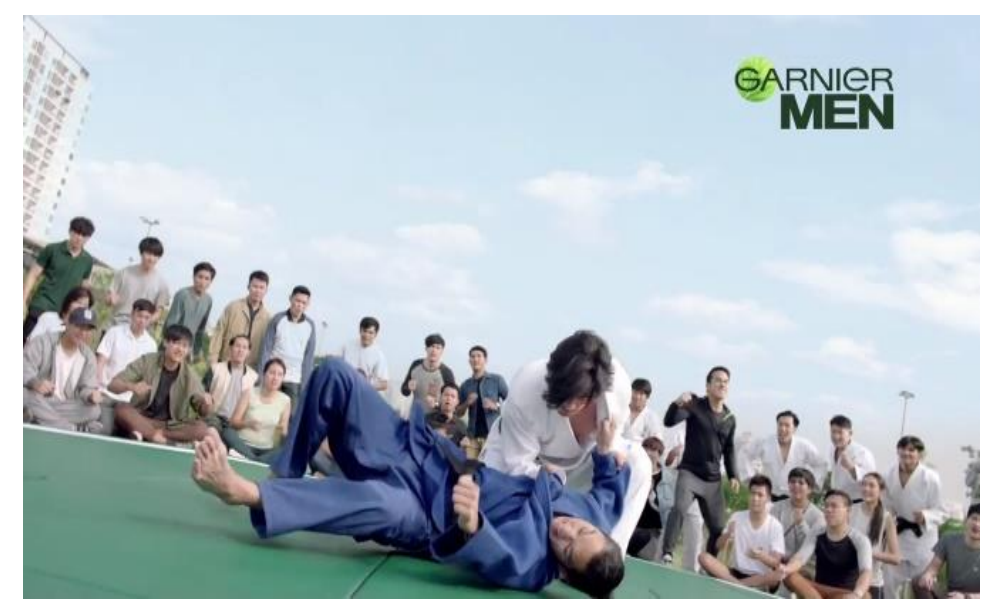

Pada potongan scene di atas menggambarkan sosok laki-laki yang berani mengambil resiko atau tantangan dengan melakukan aksi bela diri. Pada adegan iklan Garnier Men memberikan makna denotasi terhadap dua laki-laki yang terlihat sedang melakukan pertarungan. Sementara, makna konotasi yang terapat dalam adegan tersebut ialah dua sosok laki-laki yang berani berkelahi walaupun ada sebenarnya terdapat rasa takut dan resiko pada saat bertarung di area tersebut. Keberanian adalah suatu hal yang wajib dimilki oleh seorang laki-laki.
Konsep maskulinitas dalam scene di atas terlihat pada penggambaran laki-laki yang berani mengambil resiko, kuat secara fisik untuk berkelahi melindungi diri. Laki-laki tersebut menunjukkan maskulinitas dengan gaya hidup urban metropolis yang tidak pernah takut menghadapi tantangan. Hal ini diperkuat dengan mitos atau ideologi yang ada di dalamnya, yakni resiko dan tantangan adalah salah satu hal yang selalu dihadapi oleh laki-laki dan keberanian merupakan suatu hal yang wajib dimilki oleh seorang laki-laki.
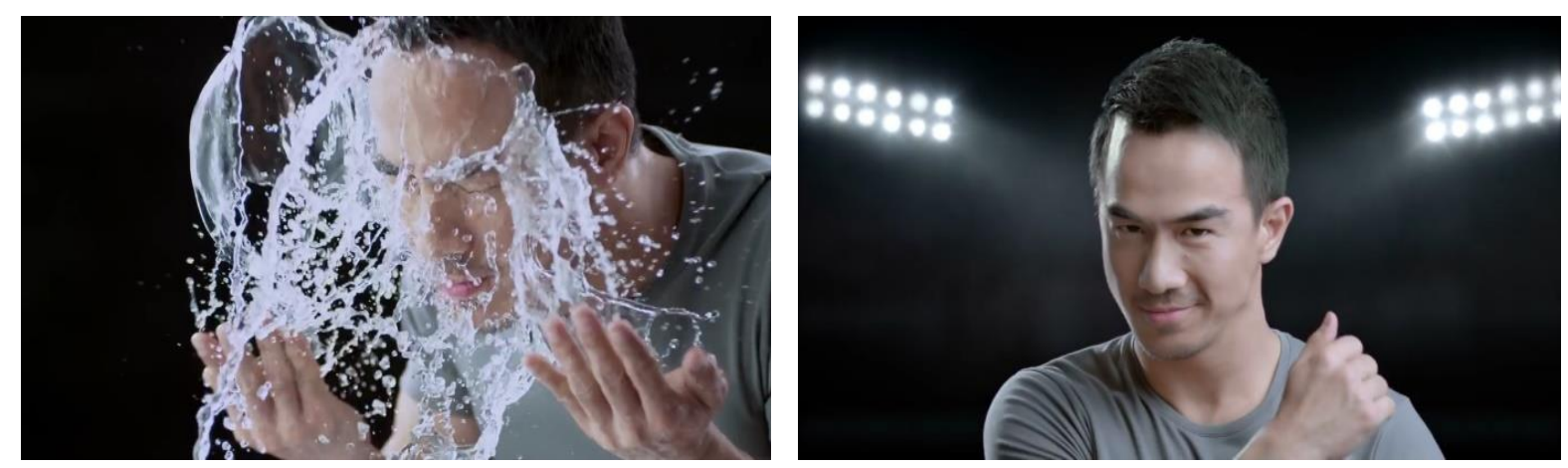
Pada potongan scene di atas menggambarkan laki-laki yang sedang mencuci muka menggunakan Garnier Men. Pada adegan iklan ini terdapat makna denotasi yang terdapat dalam penggambaran sosok laki-laki yang metroseksual, dimana laki-laki tersebut merawat penampilannya khususnya pada wajahnya dengan mencuci muka dan memakai produk Garnier Men. Dimana hal tersebut biasanya dilakukan oleh perempuan. Setelah menggunakan Garnier Men tersebut laki-laki tampak wajahnya bersih dan tampan kembali. Konsep maskulinitas pada scene ini terlihat pada perilaku laki-laki dalam merawat penampilan wajah. Sehingga kebersihan pada wajah merupakan suatu hal penting bagi laki-laki. Makna konotasi yang terdapat di dalamnya ialah hanya sebuah atau salah satu perilaku lakilaki dalam merawat penampilan wajah. Hal ini didukung dengan mitos atau ideologi yang berkembang di dalamnya, yakni kebersihan pada wajah merupakan suatu hal penting bagi laki-laki

Selain tanda-tanda semiotik pada potongan scene maupun potongan beberapa adegan dalam iklan ini, tanda verbal yang meliputi narasi yang terdapat pada iklan juga menjadi tanda semiotik yang dapat dianalisis menggunakan pendekatan Roland Barthes melalui pendekatan makna konotasi, makna denotasi, dan mitos untuk memperkuat konsep maskulinitas yang terdapat di dalamnya.

Cowok itu butuh upgrade penampilan.

Biar tetap tampil keren. Tapi, keren aja nggak cukup.

Saatnya lo upgrade sabun cuci muka lo buat \# TampilSuper

Pada teks narasi di atas merupakan teks narasi dalam iklan Garnier Men yang mendukung penggambaran sosok laki-laki maskulin dengan memiliki ciri lakilaki metroseksual. Makna konotasi dalam teks narasi tersebut terlihat pada kalimat cowok itu butuh upgrade penampilan dimana kalimat tersebut memiliki makna denotasi bahwa setiap laki-laki dipastikan butuh untuk selalu memperbarui penampilannya. Kemudian dilanjut dengan kalimat biar tetep tampil keren, kalimat ini menunjukkan bahwa sifat keren merupakan salah satu sifat yang wajib dimiliki oleh laki-laki maskulin. Yang berarti setiap lakilaki pasti membutuhkan perbaruan dalam penampilan agar tetap dapat tampil keren. Hal ini didukung dengan mitos atau ideologi yang berkembang di dalamnya, yakni konsep maskulinitas zaman sekarang meliputi ciri laki-laki metroseksual yang selalu merawat wajah mereka. Ciri ini menambah deretan ciri dalam konsep maskulinitas yang telah ada sebelumnya, seperti menganggap tinggi nilai-nilai antara kekuatan, kekuasaan, ketabahan, aksi, kendali, kemandirian, kepuasan diri, 
kesetiakawanan laki-laki, dan kerja keras.

Dalam iklan Garnier Men versi Joe Taslim dan Chico Jerikho ini jelas menunjukkan konsep maskulinitas imaji kejantanan, ketangkasan, keperkasaan, keberanian untuk menantang bahaya, keuletan, keteguhan hati, hingga keringat yang menetes, dan otot laki-laki yang menyembul atau bagian tubuh tertentu dari kekuatan daya laki-aki yang terlihat secara ekstrinsik. Hal ini juga didukung oleh model iklan memiliki image yang sangat ingin ditunjukkan oleh produk yang diiklankan. Kostum yang digunakan, serta properti yang dipakai membuat model iklan terlihat maskulin yang sesuai dengan sifat maskulin klasik, yakni narsis, macho, tangguh, dan metroseksual yang diperlihatkan dengan gaya fashionable dan kegiatan atraktif kedua model yang sangat diperhatikan pada iklan ini. Selain itu konsep maskulinitas baru juga terdapat pada iklan Garnier Men versi Joe Taslim dan Chico Jeriko, yakni representasi maskulinitas baru ditampilkan pada sosok model dalam iklan tersebut. Hal ini didukung juga dengan tanda tampilan fisik dari model yang memilki kulit bersih dan berpenampilan rapi dan terawat juga. Tampilan model iklan menggambarkan identitas dari model yang merawat diri dengan perawatan khusus. Dua sikap tersebut merupakan simbol dari gaya hidup metroseksual yang jika kita pahami lagi merupakan manipulasi dari identitas maskulin baru.

Upaya memahami makna sesungguhnya merupakan salah satu masalah filsafat yang tertua. Salah satu cara yang digunakan para ahli untuk membahas lingkup makna yang besar ini dengan membedakan antara makna denotasi dan konotasi yang pada dasarnya meliputi hal-hal yang ditunjuk oleh kata maupun tanda. Selain itu, bahasa dalam wacana linguistic bahasa diartikan sebagai sistem symbol bunyi yang memiliki makna yang bersifat arbitrer dan konvensional.

\section{SIMPULAN}

Berdasarkan hasil analisis dengan pendekatan semiotika Roland Barthes terhadap iklan Garnier Men, terdapat beberapa tanda yang merepresentasikan sifat dan ciri-ciri maskulinitas yang terdapat pada iklan Garnier Men versi Joe Taslim dan Chico Jeriko, yaitu,

Makna denotasi yang terdapat pada iklan Garnier Men versi Joe Taslim dan Chico Jeriko yaitu maskulinitas laki-laki dapat dilihat dari kegiatan yang ia lakukan, seperti kegiatan balapan sebagai salah satu aktivitas laki-laki di kota metropolis dan atraksi bela diri. Sedangkan makna konotasi yang terdapat pada iklan Garnier Men versi Joe Taslim dan Chico Jeriko yakni laki-laki maskulin merupakan laki-laki yang memiliki 
wajah bersih, bibir merah, berwajah tampan, berkulit putih, berambut lurus, percaya diri, macho, fashionable, urban dan metropolis tetapi tidak kehilangan sisi kegagahannya apabila ia mulai merawat anggota tubuhnya khususnya wajah. Karena hal ini dinilai sudah menjadi konsep maskulinitas yang baru, laki-laki maskulin ialah laki-laki yang bersih dan wangi, cenderung metroseksual.

Mitos dan ideologi yang terdapat pada iklan Garnier Men versi Joe Taslim dan Chico Jeriko adalah ideologi kapitalisme. Dimana dalam hal ini kostum dan properti diperlihatkan untuk menunjukkan tanda ideologi tersebut.

Selain itu, dapat ditarik kesimpulan bahwa representasi yang tampak adalah pembentukan makna baru bahwa maskulinitas yang awalnya merupakan gambaran dari laki-laki yang atletis, berani, dan gagah menjadi laki-laki yang juga butuh akan perawatan wajah yang putih, bersih, lembab, dan sehat. Iklan Garnier Men merupakan iklan media televisi yang mengkonstruksi makna baru bahwa produk pembersih wajah tidak hanya dipergunakan oleh wanita saja namun juga oleh lakilaki.

DAFTAR PUSTAKA

Barthes, Roland, (2004). Mitologi, (Terj. Nurhadi \& Sihabul Millah), Yogyakarta : Kreasi Wacana.
Christomy \& Yuwono. (2004). Semiotika Budaya, Depok : Pusat Penelitian Kemasyarakatan dan Budaya Direktorat Riset dan Pengabdian Masyarakat Universitas Indonesia Press

Creswell, John W. (2018). Qualitative Inquiry and Research Design: Choosing Among Five Tradition, California: Sage.

Eriyanto. (2012). Analisis Framing: Konstruksi, Ideologi, dan Politik Media. Yogyakarta: LKIS.

Hall, Stuart. (2017). Representation: Cultural Representation and Signifying Practices. London: Sage Publications.

Jewitt, C. (tt). 'Images of Men: Male Sexuality in Sexual Health Leaflets and Posters for Young People",

http:llwww.socresonline 12121 6.html

Kurniawan. (2011). Semiologi Roland Barthes. Magelang : Yayasan Indonesiatera Anggota IKAPI.

Yohanda, Yulia. (2011). Makna Cantik Dalam Iklan Televisi Citra Versi "Rumah Cantik Citra. Banten : Universitas Sultan Ageng Tirtayasa Serang. 